\title{
TAX DEDUCTIBILITY OF COMMUTING EXPENSES AND RESIDENTIAL LAND USE WITH MORE THAN ONE CENTER
}

\author{
MATTHIAS WREDE
}

CESIFO WORKING PAPER NO. 972

CAtegory 1: Public Finance

JUNE 2003

Presented at CESifo Area conference on Public Sector Economics, May 2003

\footnotetext{
An electronic version of the paper may be downloaded

- from the SSRN website: $\quad$ www.SSRN.com

- from the CESifo website: www.CESifo.de
} 


\title{
TAX DEDUCTIBILITY OF COMMUTING EXPENSES AND RESIDENTIAL LAND USE WITH MORE THAN ONE CENTER
}

\begin{abstract}
This paper analyzes the treatment of commuting expenses by the income tax code from a normative and a positive point of view within a continuous space framework with endogenous residence choices and perfect labor mobility. As commuting expenses should never be deductible from the income tax base in a first-best world, deductibility might well be the outcome of a second-best-optimum-tax approach provided that not all factors of production were mobile. Non-deductibility might be justified by a lack of instruments to internalize environmental and congestion externalities or by perfect mobility of all production factors. However, the existence of deductions in many coun-tries can be easily explained within a public choice framework by redistribution from non-commuters to commuters.
\end{abstract}

JEL Code: H21, J61, R13.

Keywords: Income tax, relief, residential land use, labor mobility, commuting expenses, optimum taxation.

\author{
Matthias Wrede \\ Department of Economics and Business \\ Administration \\ Aachen University \\ 52056 Aachen \\ Germany \\ mwr@fiwi.rwth-aachen.de
}

This paper was presented at the WZB (Berlin) and the CESifo Area Conference on Public Sector Economics 2003 (Munich). The author thanks the participants, particularly Helmut Bester, Ulrich Kamecke and Berthold Wigger, for valuable comments. The usual disclaimer applies. 


\section{Introduction}

Even within the group of industrialized countries tax rules concerning commuting expenses vary greatly. While traveling expenses to work are not deductible in many countries such as the United States and the United Kingdom, they are (at least partially) deductible in the majority of the EU countries, e.g. in Germany and the Scandinavian countries [Oscar Faber et al. (2000), pp. 42 - 43, see also Open University (2001) and $\operatorname{OECD}(1993 a, b)]$.

In view of these differences, the extent to which commuting expenses are tax deductible should be clarified from an normative economic point of view. Recently, Wrede (2001) discussed the rationale of income tax deductions for travelling expenses to work relying on a first-best two-region framework with household and worker mobility. The main efficiency argument in favor of a tax relief is that workers should not be distorted by tax rules when choosing their place of work. Wrede (2001) came to the conclusion that commuting expenses should be deductible at more than $100 \%$ in order to ensure neutrality with respect to the choice of work, taking into account the loss of leisure caused by commuting. However, if the choice of the location of residence is causal for commuting instead of the choice of the working place, implicitly preferential treatment of far-off domiciles by the tax code not only reduces tax revenue but is also inefficient. In accordance with the latter argument the US government has always taken the view that commuting expenses are personal expenses and, therefore, should not be deductible at all [see Due (1977)]. Assuming that households are attached to particular places of residences and that, therefore, household mobility is not perfect, Wrede (2001) shows that deductibility is still optimal even if households simultaneously choose the place of work and the region of residence. However, if mobility were perfect, commuting would be inefficient if people can live and work in either region.

The model employed by Wrede (2001) has some shortcomings. First, since it considers only two regions, the residence choice is just a binary choice. Second, the model assumes that people can always live where they work. However, in reality commuting is to some extent inevitable since production and housing compete for space. 
Third, the whole analysis is done within a first-best framework. Fourth, the model does not explicitly take congestion or pollution into account. This paper will overcome these weaknesses. Space will be considered as a continuous variable with a fixed number of places of work. Hence, the residence choice is no longer binary and production and living separate. The paper uses the classical approach towards residential land use in a monocentric city initiated by Alonso (1964) as its starting point and adds labor mobility by considering more than one city center. With respect to taxation, not only a first-best analysis, but also a second-best analysis is carried out. Furthermore, negative externalities of commuting are also considered.

The paper is organized as follows. Section two presents the basic model and derives necessary conditions for a first-best efficient allocation. Next, section three analyzes labor income taxation and deductibility of commuting expenses. It derives analytically first-best tax rules and analyzes numerically second-best taxation. Section four discusses briefly some extensions: externalities, additional mobility and alternative geography. Then, applying a simple public choice approach, section five discusses the issues from a positive point of view. Section six concludes.

\section{Twofold mobility and efficiency}

A region described by a straight line $[0,1]$ is considered with $\mathrm{H}$ units of land at every point. The region is occupied by a continuum of individuals that sums up to $\bar{N}$. The non-negative "number" of individuals living at point $t$ is denoted by $N(t)$. $N(t)$ is assumed to be a differentiable function with the possible exception of a finite number of points. Since each individual has to live somewhere, $\int_{0}^{1} \mathrm{~N}(\mathrm{t}) \mathrm{dt}=\overline{\mathrm{N}}$. Individuals derive utility from non-negative private consumption and housing (for simplicity directly measured in units of land). All individuals are equally productive and share the same preferences. At either end of the line there is a city (= center) denoted by A (at location 0 ) and B (at location 1) where people work. At city i, production takes place according to a linearly homogeneous, concave and twice continuously differentiable production function $\mathrm{F}\left(\mathrm{N}_{\mathrm{i}}, \mathrm{L}_{\mathrm{i}}\right)$ with positive and decreasing marginal products $\mathrm{F}_{\mathrm{N}}$ and $\mathrm{F}_{\mathrm{L}}$ and com- 
plementary factors such that $\mathrm{F}_{\mathrm{NL}}>0 .{ }^{1}$ Since each worker inelastically supplies one unit of labor, $\mathrm{N}_{\mathrm{i}}$ indicates the number of workers. $\mathrm{L}_{\mathrm{i}}$ denotes a second factor of production (for instance, additional land, natural resources, capital, etc.). For the time being, the second factor of production is immobile and inelastically supplied in each city. Note that the technology is the same in both cities. Individuals who do not live where they work use resources for commuting purposes. Assuming a simple linear transportation cost function, commuting costs of a resident at location $\mathrm{t}$ are $\mathrm{k} \mathrm{t}$, where $\mathrm{k}$ is a strictly positive real number. No particular transportation costs for the consumption good are considered. This can be justified by assuming that transportation costs for consumption goods are relatively low and/or that workers pick up consumption goods at the city after work. Individuals are mobile with respect to both the place of residence and the place of work. Mobility is perfect; transaction costs are absent. Perfect mobility ensures that at an equilibrium all individuals achieve the same utility level.

An obvious precondition for efficiency is that no two individuals exist that could reduce total commuting costs by exchanging residences. Hence, a location s should exist that divides the region into two catchment areas: all individuals living at some $\mathrm{t}<$ $\mathrm{s}$ work in city A (at location 0 ) and the residents at every $\mathrm{t}>\mathrm{s}$ are part of the working population of $\mathrm{B}$ (at location 1). Hence, $\mathrm{N}_{\mathrm{A}}=\int_{0}^{\mathrm{s}} \mathrm{N}(\mathrm{t}) \mathrm{dt}$ and $\mathrm{N}_{\mathrm{B}}=\int_{\mathrm{s}}^{1} \mathrm{~N}(\mathrm{t}) \mathrm{dt}$. Throughout the analysis it is assumed that due to a high productivity of labor and/or low commuting costs net output of an additional commuter is positive in any circumstances, i.e., $\mathrm{F}_{\mathrm{N}}\left(\overline{\mathrm{N}}, \mathrm{L}_{\mathrm{i}}\right)-\mathrm{k}>0$ for $\mathrm{i}=\mathrm{A}, \mathrm{B}$. Hence, there should be no fallow land between the two catchment areas.

Another necessary efficiency condition can be easily obtained. Efficiency in consumption requires that the marginal rates of substitution between land and consumption of all residents at a particular location have to be the same. Otherwise it would be possible to make residents at this location better off through exchanging goods and land among them. Furthermore, since utility levels are equalized among individuals, consumption patterns are the same for all residents at a particular location. Hence, equal

\footnotetext{
1 Derivatives are denoted by subscripts.
} 
distribution of land at each point is an efficiency condition. Individual consumption at point $\mathrm{t}$ is denoted by $\mathrm{c}(\mathrm{t})$ and individual housing (measured in units of land) by $\mathrm{h}(\mathrm{t})$, which is in the absence of fallow land equal to $\mathrm{H} / \mathrm{N}(\mathrm{t})$. The mobility equilibrium condition can now be written as $\mathrm{u}(\mathrm{c}(\mathrm{t}), \mathrm{h}(\mathrm{t}))=\mathrm{u}(\mathrm{c}(\varepsilon), \mathrm{h}(\varepsilon))$, for all $\mathrm{t}, \varepsilon \in[0,1]$, where $\mathrm{u}$ is a strictly twice differentiable quasi-concave utility function with positive marginal utilities. $\mathrm{h}(\mathrm{t})$ and $\mathrm{c}(\mathrm{t})$ are also differentiable functions with the possible exception of a finite number of points $t$.

In order to determine an efficient allocation, the following optimization problem has to be solved:

$$
\underset{\substack{N(t), c(t), h(t), N_{A}, N_{B}, s}}{\operatorname{Max}} \int_{0}^{1} u(c(t), h(t)) N(t) d t
$$

$$
\text { s.t. } \quad \mathrm{N}_{\mathrm{A}}=\int_{0}^{\mathrm{s}} \mathrm{N}(\mathrm{t}) \mathrm{dt}, \mathrm{N}_{\mathrm{B}}=\int_{\mathrm{s}}^{1} \mathrm{~N}(\mathrm{t}) \mathrm{dt}, \overline{\mathrm{N}}=\mathrm{N}_{\mathrm{A}}+\mathrm{N}_{\mathrm{B}}
$$

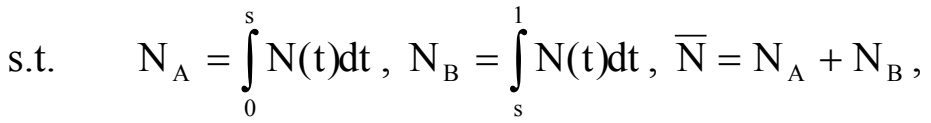

$$
H=h(t) N(t), \text { for all } t \in[0,1]
$$

$$
\mathrm{F}\left(\mathrm{N}_{\mathrm{A}}, \mathrm{L}_{\mathrm{A}}\right)+\mathrm{F}\left(\mathrm{N}_{\mathrm{B}}, \mathrm{L}_{\mathrm{B}}\right)=\int_{0}^{\mathrm{s}}(\mathrm{c}(\mathrm{t})+\mathrm{kt}) \mathrm{N}(\mathrm{t}) \mathrm{dt}+\int_{\mathrm{s}}^{1}(\mathrm{c}(\mathrm{t})+\mathrm{k}(1-\mathrm{t})) \mathrm{N}(\mathrm{t}) \mathrm{dt},
$$

(1.b) ensures that each individual lives and works at some, but possibly different locations. Due to (1.c) exactly the available land at every location is used for housing purposes. The feasibility constraint (1.d) equates production and consumption plus commuting expenses and, therefore, excludes waste of producible resources. (1.e) is the mobility equilibrium condition. ${ }^{2}$ Finally, the non-negativity constraints (1.f) are added.

In order to determine some necessary optimum conditions, it is helpful to divide the optimization problem into two subproblems. First, the optimum pattern of population $\mathrm{N}(\mathrm{t})$, consumption $\mathrm{c}(\mathrm{t})$ and housing $\mathrm{h}(\mathrm{t})$ in each catchment area will be determined

2 If the mobility equilibrium condition were not considered as a constraint, the set of efficient allocations would be much larger and an utilitarian planner would treat equals unequally provided that the income elasticity of demand for space is non-zero (see Mirrlees (1972) and Wildasin (1986)). 
provided that $\mathrm{s}, \mathrm{N}_{\mathrm{A}}$ and $\mathrm{N}_{\mathrm{B}}$ are given. Second, the optimum division of the space into two catchment areas and, therefore, the working population in each city will be determined if residences are fixed (and hence $\mathrm{N}(\mathrm{t})$ and $\mathrm{h}(\mathrm{t})$ are given). While the first problem is concerned with household mobility and the allocation of space, the second problem deals with worker mobility and the allocation of labor.

\subsection{Household mobility and the optimum allocation of space}

In order to develop a simple representation of the optimization problem concerned with household mobility, some definitions and preliminary calculations are useful. First, a transfer S from the region around city B to the city A is defined. Second, two state variables $\mathrm{M}$ and $\mathrm{X}$ are defined, with

$$
\mathrm{M}(\mathrm{t})=\mathrm{N}_{\mathrm{A}}-\int_{0}^{\mathrm{t}} \mathrm{N}(\varepsilon) \mathrm{d} \varepsilon \text { and } \mathrm{X}(\mathrm{t})=\mathrm{F}\left(\mathrm{N}_{\mathrm{A}}, \mathrm{L}_{\mathrm{A}}\right)+\mathrm{S}-\int_{0}^{\mathrm{t}}(\mathrm{c}(\varepsilon)+\mathrm{k} \varepsilon) \mathrm{N}(\varepsilon) \mathrm{d} \varepsilon
$$

Third, it is assumed that $\mathrm{c}, \mathrm{N}$ and $\mathrm{u}$ are differentiable functions at $(0,1)$. Hence, using a dot over the function symbol to denote the derivative with respect to the location, the mobility equilibrium condition can be written as $\dot{\mathrm{u}}(\mathrm{c}(\mathrm{t}), \mathrm{h}(\mathrm{t})):=\mathrm{du}(\mathrm{c}(\mathrm{t}), \mathrm{h}(\mathrm{t})) / \mathrm{dt}=0$. Using $H=h(t) N(t)$, this condition becomes

$$
\mathrm{u}_{\mathrm{c}}(\mathrm{c}(\mathrm{t}), \mathrm{H} / \mathrm{N}(\mathrm{t})) \dot{\mathrm{c}}(\mathrm{t})-\mathrm{u}_{\mathrm{h}}(\mathrm{c}(\mathrm{t}), \mathrm{H} / \mathrm{N}(\mathrm{t})) \dot{\mathrm{N}}(\mathrm{t}) \mathrm{H} / \mathrm{N}(\mathrm{t})^{2}=0
$$

Fourth, a control variable a is defined such that $a=\dot{N}$. Suppressing the time index for the sake of a simple notation and rearranging, the optimization problem for the catchment area of city A can be written as

$$
\begin{aligned}
\operatorname{Max}_{\mathrm{a}} \int_{0}^{\mathrm{s}} \mathrm{u}(\mathrm{c}, \mathrm{H} / \mathrm{N}) \mathrm{Ndt} \\
\text { s.t. } \quad \dot{\mathrm{c}}=\frac{\mathrm{u}_{\mathrm{h}}(\mathrm{c}, \mathrm{H} / \mathrm{N}) \mathrm{H}}{\mathrm{u}_{\mathrm{c}}(\mathrm{c}, \mathrm{H} / \mathrm{N}) \mathrm{N}^{2}} \mathrm{a}, \\
\dot{\mathrm{N}}=\mathrm{a}, \\
\dot{\mathrm{X}}=-(\mathrm{c}+\mathrm{kt}) \mathrm{N}, \\
\dot{\mathrm{M}}=-\mathrm{N},
\end{aligned}
$$




$$
\begin{aligned}
& \mathrm{X}(0)=\mathrm{F}\left(\mathrm{N}_{\mathrm{A}}, \mathrm{L}_{\mathrm{A}}\right)+\mathrm{S}, \mathrm{X}(\mathrm{s})=0, \mathrm{M}(0)=\mathrm{N}_{\mathrm{A}}, \mathrm{M}(\mathrm{s})=0, \\
& 0 \leq \mathrm{c} \leq \mathrm{X}, 0 \leq \mathrm{N} \leq \mathrm{M},
\end{aligned}
$$

where $\mathrm{N}_{\mathrm{A}}, \mathrm{S}$ and $\mathrm{s}$ are taken as given. The constraints are the equations of motion of the four state variable $\mathrm{c}, \mathrm{N}, \mathrm{X}$, and $\mathrm{M}$ and the boundary conditions. $\lambda_{1}-\lambda_{4}$ are the respective co-state variables. The Hamiltonian function is

$$
\begin{aligned}
& \mathrm{H}\left(\mathrm{t}, \mathrm{a}, \mathrm{c}, \mathrm{N}, \mathrm{X}, \mathrm{M}, \lambda_{1}, \lambda_{2}, \lambda_{3}, \lambda_{4}\right) \\
& \quad=\mathrm{u}(\mathrm{c}, \mathrm{H} / \mathrm{N}) \mathrm{N}+\lambda_{1} \frac{\mathrm{u}_{\mathrm{h}}(\mathrm{c}, \mathrm{H} / \mathrm{N}) \mathrm{H}}{\mathrm{u}_{\mathrm{c}}(\mathrm{c}, \mathrm{H} / \mathrm{N}) \mathrm{N}^{2}} \mathrm{a}+\lambda_{2} \mathrm{a}-\lambda_{3}(\mathrm{c}+\mathrm{kt}) \mathrm{N}-\lambda_{4} \mathrm{~N} .
\end{aligned}
$$

Applying the maximum principle, the following necessary optimum condition can be derived

$$
\left(\frac{\mathrm{u}_{\mathrm{h}}}{\mathrm{u}_{\mathrm{c}}}\right)=-\frac{\mathrm{k}}{\mathrm{h}}
$$

(see the appendix). People that live close to the city should be willing to pay more for land than those whose residences are located far away. Since all residents achieve the same utility level, people use more land and consume less of the consumption good the larger the distance to the city is (see figure 1). Moreover, the curve of the marginal rate of substitution (depicted against location) becomes flatter the more land people use and thus the further away form the city center they reside.

\section{Figure 1: Consumption, housing and location}

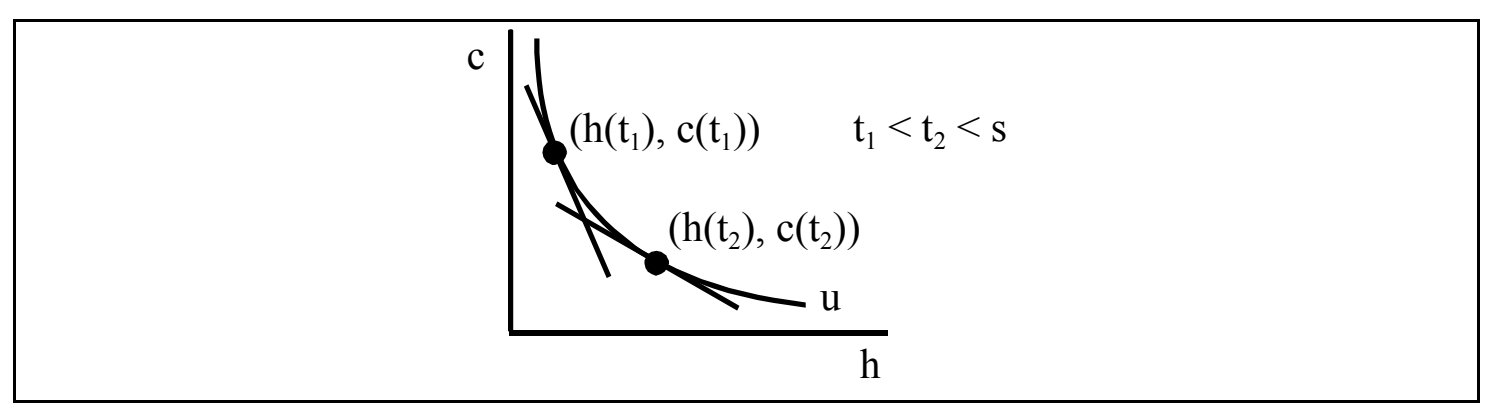

Applying the same procedure to city $B$, leads to $\left(\mathrm{u}_{\mathrm{h}} / \mathrm{u}_{\mathrm{c}}\right)=\mathrm{k} / \mathrm{h}$ for the catchment area of B. Taking into account that at s land has to be divided equally among individuals irrespective of the place of work and using the symmetry of the derivatives 
of the marginal rate of substitution, the marginal rate of substitution in the two catchment areas can be depicted as in figure 2. Furthermore, for all $\varepsilon$ with $\varepsilon \leq \min \{s, 1-\mathrm{s}\}$ :

$$
\mathrm{h}(\mathrm{s}-\varepsilon)=\mathrm{h}(\mathrm{s}+\varepsilon), \mathrm{c}(\mathrm{s}-\varepsilon)=\mathrm{c}(\mathrm{s}+\varepsilon) \text { and } \mathrm{N}(\mathrm{s}-\varepsilon)=\mathrm{N}(\mathrm{s}+\varepsilon) .
$$

This symmetry condition implies that s should be larger than (equal to, smaller than) $1 / 2$ if and only if $\mathrm{N}_{\mathrm{A}}$ is larger than (equal to, smaller than) $\overline{\mathrm{N}} / 2$.

\section{Figure 2: Marginal rate of substitution}

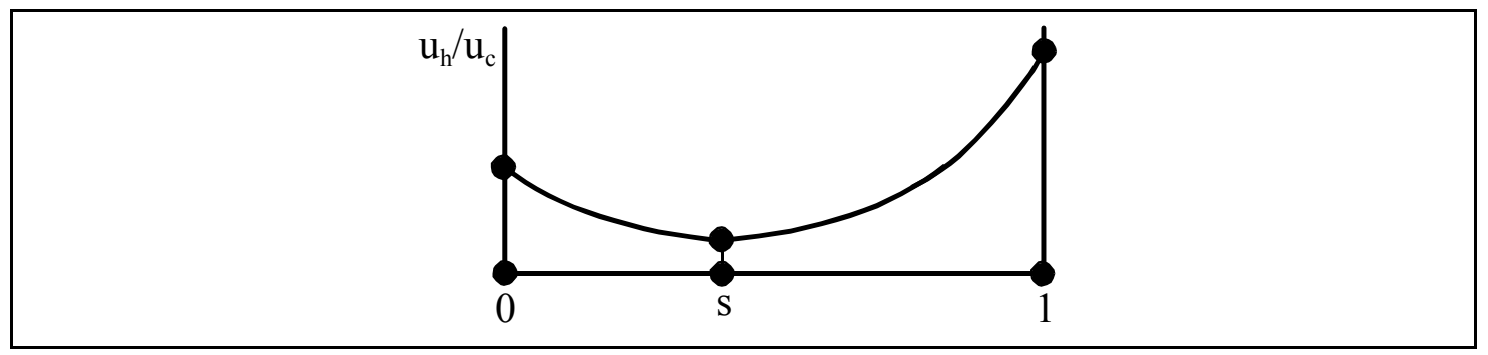

\subsection{Worker mobility and the optimum allocation of labor}

Efficiency not only requires an optimum allocation of space but also an optimum allocation of labor. If residences are determined and, hence, $\mathrm{N}(\mathrm{t})$ and $\mathrm{h}(\mathrm{t})$ are given, the distribution of the available quantity of the producible good is determined by the migration equilibrium condition and the pattern of commuting expenses. The higher total output is and the lower total commuting expenses are, the higher the consumption level and welfare are. Hence, at an optimum output minus commuting expenses is maximized. Taking $\mathrm{N}(\mathrm{t})$ for all $\mathrm{t} \in[0,1]$ as given and assuming that $\mathrm{c}(\mathrm{t})$ for all $\mathrm{t} \in[0,1]$ ensures that (1.d) - (1.f) are satisfied, the optimum allocation of labor is determined by solving

$$
\begin{aligned}
& \underset{\mathrm{s}, \mathrm{N}_{\mathrm{A}}, \mathrm{N}_{\mathrm{B}}}{ } \mathrm{F}\left(\mathrm{N}_{\mathrm{A}}, \mathrm{L}_{\mathrm{A}}\right)-\mathrm{k} \int_{0}^{\mathrm{s}} \mathrm{tN}(\mathrm{T}) \mathrm{dt}+\mathrm{F}\left(\mathrm{N}_{\mathrm{B}}, \mathrm{L}_{\mathrm{B}}\right)-\mathrm{k} \int_{\mathrm{s}}^{1}(1-\mathrm{t}) \mathrm{N}(\mathrm{T}) \mathrm{dt} \\
& \text { s.t. } \mathrm{N}_{\mathrm{A}}=\int_{0}^{\mathrm{s}} \mathrm{N}(\mathrm{t}) \mathrm{dt} \text { and } \mathrm{N}_{\mathrm{B}}=\overline{\mathrm{N}}-\mathrm{N}_{\mathrm{A}} .
\end{aligned}
$$

Substituting for $\mathrm{N}_{\mathrm{A}}$ and $\mathrm{N}_{\mathrm{B}}$, the first-order condition with respect to $\mathrm{s}$ can be written as

$$
\mathrm{F}_{\mathrm{N}}\left(\mathrm{N}_{\mathrm{A}}, \mathrm{L}_{\mathrm{A}}\right)-\mathrm{ks}=\mathrm{F}_{\mathrm{N}}\left(\mathrm{N}_{\mathrm{B}}, \mathrm{L}_{\mathrm{B}}\right)-\mathrm{k}(1-\mathrm{s}) \text {. }
$$


At the border between the two catchment areas, the marginal product of labor net of commuting expenses should be independent of the place of work. If, for example, the marginal product of labor in city A net of commuting expenses at the border exceeded the marginal product of labor in city B net of commuting expenses, the catchment area of city A should be enlarged at the expense of city B.

Both catchment areas should be of equal size, i.e., $s=1 / 2$, if labor intensities were the same, i.e., if $n_{A}=n_{B}$, where $n_{i}=N_{i} / L_{i}, i=A$, B. If the labor intensity in city A were higher than in city B, the marginal product of labor would be smaller in A than in $\mathrm{B}$, and $\mathrm{s}$ has to be lower than $1 / 2$. Otherwise (4) would be violated. Hence, candidates for optima are the following allocations of the factors of production: ${ }^{3}$

(5.a) $\mathrm{F}_{\mathrm{N}}^{\mathrm{A}}=\mathrm{F}_{\mathrm{N}}^{\mathrm{B}}, \mathrm{n}_{\mathrm{A}}=\mathrm{n}_{\mathrm{B}}, \mathrm{s}=1 / 2$,

(5.b) $\mathrm{F}_{\mathrm{N}}^{\mathrm{A}}>\mathrm{F}_{\mathrm{N}}^{\mathrm{B}}, \mathrm{n}_{\mathrm{A}}<\mathrm{n}_{\mathrm{B}}, \mathrm{L}_{\mathrm{A}}>\mathrm{L}_{\mathrm{B}}, \mathrm{N}_{\mathrm{A}}>\mathrm{N}_{\mathrm{B}}, \mathrm{s}>1 / 2$,

(5.c) $\mathrm{F}_{\mathrm{N}}^{\mathrm{A}}>\mathrm{F}_{\mathrm{N}}^{\mathrm{B}}, \mathrm{n}_{\mathrm{A}}<\mathrm{n}_{\mathrm{B}}, \mathrm{N}_{\mathrm{A}} \leq \mathrm{N}_{\mathrm{B}}, \mathrm{s}>1 / 2$,

(5.d) $\mathrm{F}_{\mathrm{N}}^{\mathrm{A}}<\mathrm{F}_{\mathrm{N}}^{\mathrm{B}}, \mathrm{n}_{\mathrm{A}}>\mathrm{n}_{\mathrm{B}}, \mathrm{L}_{\mathrm{A}}<\mathrm{L}_{\mathrm{B}}, \mathrm{N}_{\mathrm{A}}<\mathrm{N}_{\mathrm{B}}, \mathrm{s}<1 / 2$,

(5.e) $\mathrm{F}_{\mathrm{N}}^{\mathrm{A}}<\mathrm{F}_{\mathrm{N}}^{\mathrm{B}}, \mathrm{n}_{\mathrm{A}}>\mathrm{n}_{\mathrm{B}}, \mathrm{N}_{\mathrm{A}} \geq \mathrm{N}_{\mathrm{B}}, \mathrm{s}<1 / 2$.

\subsection{The optimum allocation of labor and space}

An interesting question is whether all five cases described in the previous section are possible solutions of the optimization problem if the allocation of residences is also considered. The allocation (5.a) seems to be a natural candidate. Output in both regions would be the same. However, since this case requires that $\mathrm{s}=1 / 2$, it can only be efficient if $\mathrm{N}_{\mathrm{A}}=\mathrm{N}_{\mathrm{B}}$ and thus $\mathrm{L}_{\mathrm{A}}=\mathrm{L}_{\mathrm{B}}$. Otherwise the symmetry condition (3) would be violated. (5.b) and (5.d) are also plausible candidates when the second factor of production is indeed immobile since the larger region would be occupied by a larger population. However, (5.c) and (5.e) cannot be optima, since these cases assign the larger territory to the smaller population, which directly contradicts the symmetry condition (3).

$3 \mathrm{~F}_{\mathrm{j}}^{\mathrm{i}}$ is used as an abbreviation for $\mathrm{F}_{\mathrm{j}}\left(\mathrm{N}_{\mathrm{i}}, \mathrm{L}_{\mathrm{i}}\right)$ with $\mathrm{i}=\mathrm{A}, \mathrm{B}$ and $\mathrm{j}=\mathrm{N}, \mathrm{L}$. 


\section{Wage tax, commuting expenses and efficiency}

This section considers the impact of wage taxes on the allocation of space and labor within the framework developed in the previous section. Competitive markets are assumed. The consumption good is used as numeraire and its price is normalized to one. In city $i$ the wage rate is denoted by $\mathrm{w}_{\mathrm{i}}$, and the price of the second immobile factor of production is indicated by $\mathrm{v}_{\mathrm{i}}$. Profit maximization at competitive markets in the cities leads to

$$
\mathrm{F}_{\mathrm{N}}^{\mathrm{i}}=\mathrm{w}_{\mathrm{i}} \text { and } \mathrm{F}_{\mathrm{L}}^{\mathrm{i}}=\mathrm{v}_{\mathrm{i}}
$$

for $\mathrm{i}=\mathrm{A}, \mathrm{B}$. Due to constant returns to scale, the firms' profits are zero. All individuals own identical shares in land and the second factor of production. Hence, rent income per person is

$$
R=\left(v_{A} L_{A}+v_{B} L_{B}+H \int_{0}^{1} q(t) d t\right) / \bar{N},
$$

where $q(t)$ denotes the price of one unit of land at location $t$. A wage tax is levied at rate $\tau, 0 \leq \tau<1$. A fraction $\beta$ of the commuting expenses is deductible from the tax base of the wage tax such that the government effectively subsidizes commuting expenses at a rate $\beta \tau$. Tax revenue per person is

$$
\mathrm{T}=\tau\left(\mathrm{w}_{\mathrm{A}} \mathrm{N}_{\mathrm{A}}+\mathrm{w}_{\mathrm{B}} \mathrm{N}_{\mathrm{B}}-\beta \mathrm{k}\left(\int_{0}^{\mathrm{s}} \mathrm{tN}(\mathrm{t}) \mathrm{dt}+\int_{\mathrm{s}}^{1}(1-\mathrm{t}) \mathrm{N}(\mathrm{t}) \mathrm{dt}\right)\right) / \overline{\mathrm{N}},
$$

if $s$ divides the territory into two catchment areas. In the remaining part of the paper it is simply assumed that lump-sum taxation is impossible and that the government has to levy a wage tax.

The individuals' decisions can be seen as a two-stage process. In the first stage, individuals make a decision of residence and choose the city of employment. In the second stage, they decide on consumption and housing, taking prices as given. Production takes place and goods and housing markets clear. The analysis starts with the second stage. As will be shown in a moment, consumption and housing are uniquely de- 
termined by the location. Hence, any subscript that indicates a particular person is superfluous. A worker at city A who resides at location $t$ faces the budget constraint

$$
\mathrm{c}(\mathrm{t})=(1-\tau) \mathrm{w}_{\mathrm{A}}-(1-\beta \tau) \mathrm{kt}-\mathrm{q}(\mathrm{t}) \mathrm{h}(\mathrm{t})+\mathrm{R} .
$$

A Worker at B faces a similar restriction. A household maximizes utility $u(c(t), h(t))$ with respect to the budget constraint. Hence, $\mathrm{u}_{\mathrm{h}} / \mathrm{u}_{\mathrm{c}}=\mathrm{q}$. The price mechanism ensures that marginal rates of substitution of all residents at one particular location are the same.

The equilibrium at the first stage of the game is determined by the equal-utility condition. First, this mobility equilibrium condition ensures that the consumption pattern is uniquely determined by the location of residence since the relative price of land $\mathrm{q}$ and, therefore, the marginal rate of substitution are the same for all residents at this location. Second, the mobility equilibrium condition in each catchment area can be written as $\dot{\mathrm{u}}=0$. In the catchment area of city A the derivative of utility with respect to location is $\dot{\mathrm{u}}=\mathrm{u}_{\mathrm{c}}(-(1-\beta \tau) \mathrm{k}-\dot{\mathrm{q}} \mathrm{h}-\mathrm{q} \dot{\mathrm{h}})+\mathrm{u}_{\mathrm{h}} \dot{\mathrm{h}}=\mathrm{u}_{\mathrm{c}}(-(1-\beta \tau) \mathrm{k}-\dot{\mathrm{q}} \mathrm{h})$. By this observation and similar reasoning for the catchment area of $\mathrm{B}$, the mobility equilibrium condition implies

$$
\dot{\mathrm{q}}=-(1-\beta \tau) \mathrm{k} / \mathrm{h} \text { for } \mathrm{t}<\mathrm{s} \text { and } \dot{\mathrm{q}}=(1-\beta \tau) \mathrm{k} / \mathrm{h} \text { for } \mathrm{t}>\mathrm{s} \text {. }
$$

The so-called residential bid-rent function $\mathrm{q}(\mathrm{t})$ has a negative slope in catchment area $A$ and a positive slope in catchment area $B$ (when $\beta \tau<1$ ). Third, from the mobility equilibrium condition follows that labor income net of taxes and commuting expenses at location $s$ has to be independent of the city of work. Hence, using the profit maximization conditions:

$$
(1-\tau) \mathrm{F}_{\mathrm{N}}\left(\mathrm{N}_{\mathrm{A}}, \mathrm{L}_{\mathrm{A}}\right)-(1-\beta \tau) \mathrm{ks}=(1-\tau) \mathrm{F}_{\mathrm{N}}\left(\mathrm{N}_{\mathrm{B}}, \mathrm{L}_{\mathrm{B}}\right)-(1-\beta \tau) \mathrm{k}(1-\mathrm{s})
$$

Finally, the symmetry condition (3) is obviously irrespective of the tax parameters fulfilled since the price of land and, therefore, the marginal rate of substitution between land and consumption and utility is the same at $\mathrm{s}$ for workers in $\mathrm{A}$ and $\mathrm{B}$, and the price increases in both directions with the same speed. 
Comparing the market equilibrium conditions (6) and (7) to the necessary efficiency conditions (2) and (4), the efficiency properties of the market equilibrium, the impact of taxation can be described. As a starting point, the first proposition states a non-surprising result.

Proposition 1: In the absence of taxation, the market equilibrium is efficient.

In the presence of a wage tax, in general the allocation of space and labor will not be first-best efficient. An obvious lemma describes the relationship between equilibrium conditions and efficiency conditions.

Lemma: (a) If $\beta=0$, the choice of residence is not distorted. (b) If $\beta=1$, the choice of the working place is not distorted.

The lemma states sufficient conditions for (partial) efficiency. However, these are contradictory. The next proposition shows that there is one important case where neither the allocation of space nor the allocation of labor is distorted even in the presence of taxes. For this purpose it is assumed that the tax rate is strictly positive and that taxation net of deductions has to fulfill a particular revenue requirement: $\mathrm{T}=\overline{\mathrm{T}}$.

Proposition 2: In the presence of taxation, a first-best optimum can be achieved if and only if commuting expenses are not deductible $(\beta=0)$ and if the second factor of production is symmetrically distributed, such that both catchment areas are of equal size (s $=1 / 2$ ) and marginal products of labor are equalized.

Proof: (a) Sufficiency is obvious. (b) $\beta=0$ is obviously necessary to ensure an undistorted choice of residence within each catchment area. If $\beta=0$ and $\tau \neq 0$, (7) and (4) coincide only if $F_{N}^{A}=F_{N}^{B}$. Due to the symmetry condition this requires $N_{A}=N_{B}$ (and therefore $\mathrm{L}_{\mathrm{A}}=\mathrm{L}_{\mathrm{B}}$ ) and that $\mathrm{s}=1 / 2$.

Provided that space and factors of production are symmetrically allocated at an optimum, not only output net of commuting expenses but also gross output is maximized. The level of taxation is irrelevant in the symmetric case since the wage tax does not 
interfere with the choice of working place. In this special case, the tax is actually a lump sum tax.

From this proposition follows immediately that taxation becomes a second-best problem if an asymmetric allocation is optimal. In an asymmetric environment a wage tax unavoidably distorts the choice of residence and / or the choice of the working place. The main theorem of second-best theory suggests that minimizing the number of distortions is not the necessarily best taxing strategy. The next proposition confirms this suggestion.

Proposition 3: If the second factor of production is asymmetrically distributed, a second-best optimum tax policy might be characterized by a strictly positive rate of deduction $\beta$.

The existence statement of this proposition can be proven by numerical calculations. If utility is quasi-linear with $\mathrm{u}=\mathrm{c}(\mathrm{t})+\ln \mathrm{h}(\mathrm{t})$, housing expenses are independent of income: $\mathrm{q} h=1$. The price of land and the population density $N(\mathrm{t})=\mathrm{H} / \mathrm{h}(\mathrm{t})=\mathrm{H} \mathrm{q}(\mathrm{t})$ are exponential functions:

$$
\mathrm{q}(\mathrm{t})=\mathrm{q}(\mathrm{s}) \mathrm{e}^{(1-\beta \tau) \mathrm{k}(\mathrm{s}-\mathrm{t})} \text { for } \mathrm{t} \leq \mathrm{s} \text { and } \mathrm{q}(\mathrm{t})=\mathrm{q}(\mathrm{s}) \mathrm{e}^{(1-\beta \tau) \mathrm{k}(\mathrm{t}-\mathrm{s})} \text { for } \mathrm{t} \geq \mathrm{s}
$$

$\mathrm{N}_{\mathrm{A}}$, s and $\mathrm{q}(\mathrm{s})$ are determined by the equilibrium condition (7) and the population constraints

$$
\mathrm{N}_{\mathrm{A}}=\int_{0}^{\mathrm{s}} \mathrm{N}(\mathrm{t}) \mathrm{dt}=\mathrm{Hq}(\mathrm{s}) \int_{0}^{\mathrm{s}} \mathrm{e}^{(1-\beta \tau) \mathrm{k}(\mathrm{s}-\mathrm{t})} \mathrm{dt} \quad \text { and } \quad \mathrm{N}_{\mathrm{A}}=\overline{\mathrm{N}}-\mathrm{Hq}(\mathrm{s}) \int_{\mathrm{s}}^{1} \mathrm{e}^{(1-\beta \tau) \mathrm{k}(\mathrm{t}-\mathrm{s})} \mathrm{dt}
$$

In order to simplify, the production function is of the Cobb-Douglas type: $\mathrm{F}=$ $\mathrm{AN}^{\alpha} \mathrm{L}^{1-\alpha}$. The parameters are $\mathrm{H}=100, \overline{\mathrm{N}}=100, \mathrm{~L}_{\mathrm{A}}=2, \mathrm{~L}_{\mathrm{B}}=1, \mathrm{~A}=10$ and $\alpha=0.5$. If $\mathrm{k}=0.5$ and $\overline{\mathrm{T}}=0.172837$ (which is also obtained if $\beta=0$ and $\tau=0.2$ ), the second-best optimum is given by $\beta=0.385715$ and $\tau=0.211755$. Too few people would belong to the catchment area of city A and s would be too low if commuting expenses were not deductible at all. Although tax deductibility creates incentives to reside too far from the working place, it also makes it attractive to commute to a place of work which is further away but where labor is more productive. Even if commuting expenses were not de- 
ductible, more people will work in the more productive city. Hence, this city is already surrounded by a larger catchment area which is, due to the distortion of the choice of the working place, too small. On average commuting distances are too short. Tax deductibility leads to a beneficial shift of workers from the less productive to the more productive city.

\section{Extensions}

This section discusses briefly three extensions: externalities, additional mobility and alternative geography.

\subsection{Externalities and deductibility of commuting expenses}

Congestion and environmental externalities reduce the merits of commuting and make the scope for tax deductibility smaller. This will be shown for the analytically simpler case of environmental externalities. For that purpose, a public bad (pollution)

$$
\mathrm{b}=\mathrm{b}\left(\int_{0}^{\mathrm{s}} \mathrm{tN}(\mathrm{t}) \mathrm{dt}+\int_{\mathrm{s}}^{1}(1-\mathrm{t}) \mathrm{N}(\mathrm{t}) \mathrm{dt}\right), \text { with } \mathrm{b}^{\prime}>0 \text { and } \mathrm{b}^{\prime \prime} \geq 0
$$

is considered. If utility is quasi-linear with $\mathrm{u}=\mathrm{c}+\psi(\mathrm{h})-\varphi(\mathrm{b}), \psi^{\prime}>0, \psi^{\prime \prime}<0, \varphi^{\prime}>0$ and $\varphi^{\prime \prime}>0$, the two efficiency conditions are simply

$$
\begin{aligned}
& \left(\mathrm{u}_{\mathrm{h}} / \mathrm{u}_{\mathrm{c}}\right)=-\left(\mathrm{k}+\overline{\mathrm{N}} \varphi^{\prime} \mathrm{b}^{\prime}\right) / \mathrm{h}, \text { for } \mathrm{t}<\mathrm{s},\left(\mathrm{u}_{\mathrm{h}} / \mathrm{u}_{\mathrm{c}}\right)=\left(\mathrm{k}+\overline{\mathrm{N}} \varphi^{\prime} \mathrm{b}^{\prime}\right) / \mathrm{h}, \text { for } \mathrm{t}>\mathrm{s}, \\
& \mathrm{F}_{\mathrm{N}}^{\mathrm{A}}-\left(\mathrm{k}+\overline{\mathrm{N}} \varphi^{\prime} \mathrm{b}^{\prime}\right) \mathrm{s}=\mathrm{F}_{\mathrm{N}}^{\mathrm{B}}-\left(\mathrm{k}+\overline{\mathrm{N}} \varphi^{\prime} \mathrm{b}^{\prime}\right)(1-\mathrm{s})
\end{aligned}
$$

If an emission tax is levied at a constant rate e per mile and if commuters completely ignore the impact of their behavior on the environmental quality, the respective market equilibrium conditions are

$$
\begin{aligned}
& \dot{\mathrm{q}}=-(1-\beta \tau)(\mathrm{k}+\mathrm{e}) / \mathrm{h}, \text { for } \mathrm{t}<\mathrm{s}, \dot{\mathrm{q}}=(1-\beta \tau)(\mathrm{k}+\mathrm{e}) / \mathrm{h} \text { for } \mathrm{t}>\mathrm{s}, \\
& (1-\tau) \mathrm{F}_{\mathrm{N}}^{\mathrm{A}}-(1-\beta \tau)(\mathrm{k}+\mathrm{e}) \mathrm{s}=(1-\tau) \mathrm{F}_{\mathrm{N}}^{\mathrm{B}}-(1-\beta \tau)(\mathrm{k}+\mathrm{e})(1-\mathrm{s})
\end{aligned}
$$

provided that emission tax payments are also (partially) deductible from the tax base. The following proposition analyzes the relationship between the degree of internalization and tax deductibility. 
Proposition 4: If the emission tax is too low $\left(\mathrm{e}<\overline{\mathrm{N}} \varphi^{\prime} \mathrm{b}^{\prime}\right)$ and if the second factor of production is asymmetrically allocated, then an efficient choice of residence requires $\beta$ $<0$ and an efficient choice of the working place $\beta<1$.

This result suggests that at an second-best optimum the degree of deductibility is lower than in the absence of negative external effects if the emission tax internalizes the external effect only partially. If, in contrast, the emission tax were too high, an efficient choice of residence would require $\beta>0$ and an efficient choice of the working place $\beta>$ 1.

The qualitative result of the proposition holds if congestion externalities are considered. Finally, it should be stressed that this section has oversimplified by assuming that all trips to cities are made for commuting purposes. If other purposes are taken into account, reducing the proportion to which commuting expenses are deductible becomes a less well suited substitute for missing Pigouvian taxes.

\subsection{Additional mobility and deductibility of commuting expenses}

So far it has been assumed that the second factor of production is immobile. If, however, this factor were mobile, a first best optimum is additionally characterized by equal marginal products of this production factor and, therefore, equal labor intensities. If, however, labor intensities were equalized across cities, efficient allocation of labor together with the symmetry condition requires a symmetrical allocation of labor and residents. Thus:

$$
\mathrm{F}_{\mathrm{N}}^{\mathrm{A}}=\mathrm{F}_{\mathrm{N}}^{\mathrm{B}}, \mathrm{F}_{\mathrm{L}}^{\mathrm{A}}=\mathrm{F}_{\mathrm{L}}^{\mathrm{B}}, \mathrm{n}_{\mathrm{A}}=\mathrm{n}_{\mathrm{B}}, \mathrm{L}_{\mathrm{A}}=\mathrm{L}_{\mathrm{B}}, \mathrm{N}_{\mathrm{A}}=\mathrm{N}_{\mathrm{B}}, \mathrm{s}=1 / 2
$$

Because of commuting expenses, the allocation is determined. In the absence of commuting expenses any allocation of both production factors with identical labor intensities would be equally good.

Due to the symmetry, as a corollary of proposition $\mathbf{2}$ the following statement can be derived. 
Corollary: In the presence of taxation and perfect mobility of all factors of production, a first-best optimum can be achieved if and only if commuting expenses are not deductible $(\beta=0)$.

The mobile second factor of production enforces equal labor intensities and the zero deduction rate ensures an efficient choice of residences. An asymmetric equilibrium could not exist because of the mobility equilibrium condition.

If production were not restricted to the cities $\mathrm{A}$ and $\mathrm{B}$, it should take place along the entire line. Because of convex preferences, the population density should be uniform $(\mathrm{N}(\mathrm{t}) \equiv \overline{\mathrm{N}})$. Commuting would be inefficient and people should work were they live. Tax deductibility of commuting expenses would be superfluous. With constant returns to scale, agglomeration and commuting are rooted in the immobility of production factors and locations of production. If, in contrast, production were characterized by increasing returns to scale, agglomeration and commuting would be efficient even if all production factors were mobile and if production were not restricted to particular locations. In order to determine the impact of taxation, a detailed knowledge of agglomeration forces is necessary. If, however, a symmetric allocation were efficient and also the equilibrium outcome (for instance with two cities at $1 / 4$ and $3 / 4$ and $s=1 / 2$ ), a zero tax deductibility rate would be optimal provided that gross wages are given by marginal products of labor.

\subsection{Geography and deductibility of commuting expenses}

Up to now space has been modeled in the most simplest way: Two cities are located at the ends of a straight line and people live in between. Results might be different if geography were altered.

First, commuting expenses should be non-deductible if the catchment areas were separated by an unoccupied area because of a ceiling on floorspace per person. If choices were restricted by $h(t) \leq H$ ( since the "number" of persons $N(t)=H / h(t)$ has to exceed one) and if the region were sparsely populated, the centrally located area would be unoccupied even if the price of land were zero. Tax deductibility could not have any positive impact since the choice of the working place is not directly distorted by the 
wage tax. Separation of catchment areas restores the monocentric city model. Tax deductions would distort the choice of residences and would increase total gross commuting costs.

Second, the results stated by the propositions hold true if more than one road connects the two cities, for example, if A and B are located on a circle [see figure 3.a]. Moreover, if the cities are not located at the ends of the line [see figure 3.b], the qualitative results do not change. Even if more than one dead-end street starts at both cities [see figure 3.c], the analysis is still valid. Finally, if there are more than two cities, either located on a straight line or on a circle, the analysis is in principle the same. However, if A and B did not mark the ends of the road [as in figures 3.b and c], the optimum catchment area of the city that is endowed with a higher quantity of the second factor of production might even capture the other city's environs. The working population of the less productive city would completely live at one side of the city. But even in this case non deductible commuting expenses would distort the allocation of labor.

\section{Figure 3: Alternative road networks}

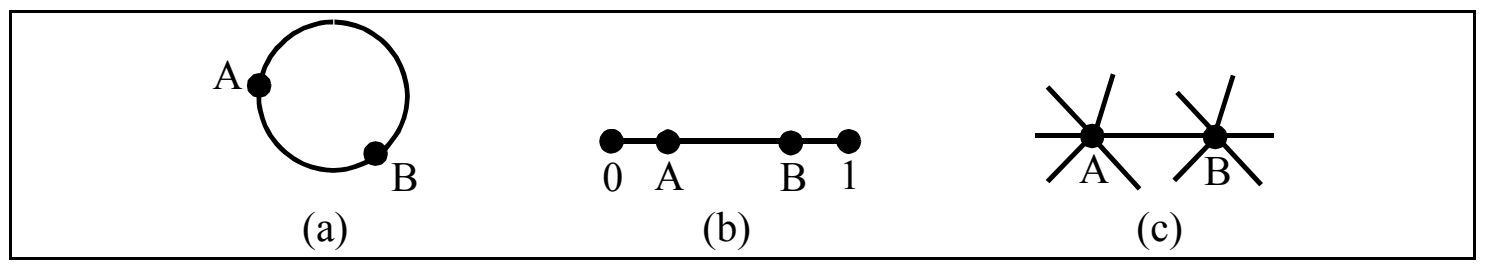

Third, if for any given quantities of the second production factor and of land the population per mile shrinks, the distortion of the allocation of labor through the tax system becomes less strong and tax deductions should be reduced. For example, when the number of dead-end streets in the case described by figure 3.c increases, ceteris paribus the optimum tax deduction rate should shrink. If the number of streets goes to infinity, commuting expenses should not be deductible.

\section{Exploitation by commuters}

Although partial deduction of commuting expenses might be a second-best optimum tax policy, the basic model as well as the extensions have shown that a zero deduction rate 
is nevertheless often optimal. Since commuting expenses are deductible in several countries, an interesting question is whether commuters who live far from the cities are willing to exploit non-commuters through tax deductibility even if commuting expenses should not be deductible for reasons of efficiency. In order to answer this question a simple three-stage political economy model is employed. At the first stage, applying the majority rule, perfectly foresighted and utility maximizing citizens decide on the tax rate $\tau$ and the rate of deduction $\beta$. Any other ways of redistribution, in particular lumpsum redistribution, are excluded by assumption. At the second stage, individuals decide on residences and working places. At the third stage, production takes place and taxes are levied. Tax revenue is redistributed in a lump-sum way and people consume. The second and third stages were described by the basic model of this paper. To strengthen the efficiency argument, the choice of working place is assumed away by considering just one city where people work located at point 0 , i.e., by arguing in the monocentric city framework.

If all individuals were equally endowed and if preferences were also identical, non-commuters could not be exploited by commuters since perfect mobility ensures that all citizens are equally well off. Some ex-ante heterogeneity is necessary. If, for instance, the population consisted of groups with different labor productivity and, hence, different income, the population would be stratified ex post as well, provided that the demand for space is a monotonically increasing function of income. When commuting costs per mile are independent of income, the wealthy have a flatter bid-rent function. Consequently the poor occupy land close to the city center ${ }^{4}$. In this paper, heterogeneity with respect to "distance aversion" will be considered. The population is divided into two groups whose members have different preferences for distance but are otherwise identical. Utility is quasi-linear with $\mathrm{u}_{\mathrm{i}}=\mathrm{c}_{\mathrm{i}}+\psi\left(\mathrm{h}_{\mathrm{i}}\right)-\mathrm{n}_{\mathrm{i}} \mathrm{t}, \mathrm{i}=1,2$, with $\psi^{\prime}>0$, $\psi^{\prime \prime}<0$, and $\mathrm{n}_{1}>\mathrm{n}_{2}$. A higher $\mathrm{n}_{\mathrm{i}}$ indicates a higher aversion to distance. At the equilibrium individuals with high distance aversion $\left(\mathrm{n}_{1}\right)$, i.e., the members of the first group,

4 This is the prediction of the theory of income segregation developed by Alonso (1964) and Muth (1969). 
live closer to the city than members of the second group because of the magnitudes of the bid-rent curves' slopes:

$$
\left|\dot{\mathrm{q}}_{1} / \mathrm{q}_{1}\right|=(1-\beta \tau) \mathrm{k}+\mathrm{n}_{1}>(1-\beta \tau) \mathrm{k}+\mathrm{n}_{2}=\left|\dot{\mathrm{q}}_{2} / \mathrm{q}_{2}\right| .
$$

The boundary is denoted by s. This holds true whether income is taxed or not and whether commuting expenses are deductible or not. The equilibrium is characterized by segregation [see figure 4.a, where the bid-rent-curves are depicted ].

\section{Figure 4: Heterogeneity and deductibility of commuting expenses}

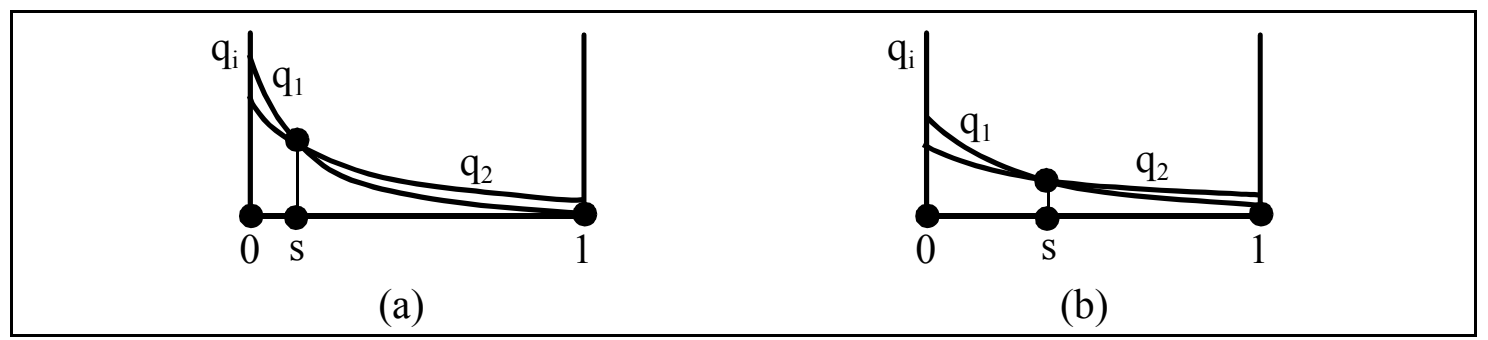

If (for the sake of simplicity) the entire income is taxable and gross income per person is denoted by $y$, than tax revenue per person is

$$
\mathrm{T}=\tau \mathrm{y}-\tau \beta \mathrm{k}\left(\int_{0}^{\mathrm{s}} \mathrm{tN}_{1}(\mathrm{t}) \mathrm{dt}+\int_{\mathrm{s}}^{1} \mathrm{tN}_{2}(\mathrm{t}) \mathrm{dt}\right) /\left(\overline{\mathrm{N}}_{1}+\overline{\mathrm{N}}_{2}\right) \text {, }
$$

where $\bar{N}_{i}$ denotes the "number" of individuals belonging to group $i$ and $N_{i}(t)$ the density of group i at location t. Since gross income is exogenous and tax revenue is redistributed in a lump-sum way, only $\tau \beta$ matters not $\beta$ alone.

Tax deductibility of commuting expenses affects citizens in two ways. First, it distorts the choice of residences. The bid-rent curve becomes flatter. People want to live farther away from the city. This first effect hurts both groups. The second group, living far away from the city, is not only harmed because the allocation of land within their group is distorted, but also because the other group expands their territory [see figure 4.b]. Second, it redistributes resources from non-commuters and short-distance commuters to long-distance commuters. The second effect, therefore, benefits the group with the higher preference for distance at the expense of the first group. Putting both effects together, it becomes obvious that the first group clearly opposes tax deduction of 
commuting expenses. Hence, tax deduction can only be the outcome of the vote at the first stage of the game if the second group is the majority. Furthermore, if the share of the second group goes to one, the distortionary effect exceeds the distribution effect such that even the second group rejects tax deductibility of commuting expenses. ${ }^{5}$ However, by numerical calculations it could be shown that in between a non-zero rate of tax deductibility is the outcome of the game. If, for example, $\psi(h)=\ln (\mathrm{h})$ and $\mathrm{H}=3.14, \mathrm{k}=$ $2, \mathrm{n}_{1}=2, \mathrm{n}_{2}=1, \overline{\mathrm{N}}_{1}=100$ and $\overline{\mathrm{N}}_{2}=100+\varepsilon$, where $\varepsilon$ is close to zero, the majority would set $\tau \beta=0.256796$.

The next proposition summarizes the findings.

Proposition 5: If the share of the long-distance commuters is higher than $1 / 2$ but sufficiently low, utility functions and parameters such that the majority exploits the minority by an inefficient non-zero deduction rate for commuting expenses exist.

This qualitative result would still hold if the population were divided into more than two groups.

\section{Concluding remarks}

This paper has analyzed the treatment of commuting expenses by the income tax code from a normative and a positive point of view within a continuous-space framework with endogenous residence choices and perfect labor mobility. The following main results were derived.

First, in order to avoid a distortion of residential land use, commuting expenses should never be deductible from the income tax base in a first-best world. Hence, in a monocentric city deductibility is clearly inefficient.

Second, if some factors of production were immobile and asymmetrically allocated, a first-best optimum is unattainable if the government has to levy a wage tax. In order to minimize the excess burden with respect to the distortion of residential land use and the distortion of the geographical pattern of labor supply, it could be right to par-

5 If the share were equal to one, redistribution would be impossible. 
tially deduct commuting expenses from the income tax base. The analysis of this paper, therefore, achieves, for quite different reasons, a similar result as Wrede (2000). He showed that in a second-best world with endogenous labor supply, but in the absence of mobility, time-saving commuting expenditure (e.g., the choice of the faster car instead of the slower public transportation system) should be deducted only partially to reduce distortions due to high wages taxes.

Third, non-deductibility might be justified by a lack of instruments to internalize environmental and congestion externalities [for a recent analysis of alternative policies for reducing traffic congestion see Parry (2002)]. The qualitative result holds if congestion externalities are considered. This is certainly not the first paper that has analyzed substitutes for direct Pigouvian taxes to internalize traffic externalities. For example, using a calibrated numerical model, recently Chia, Tsui and Whalley (2001) considered ownership taxes as congestion correcting instruments. Calthrop (2001) analyzes a congestion toll when trips are made for different purposes but when the administrative costs of a differentiated tolling system are prohibitively high. He argues for a uniform congestion toll combined with a subsidy to commuters since the degree of Hicksian complementarity of commuting with leisure is comparatively small. However, when one takes, in contrast to Calthrop (2001), labor mobility into account, subsidizing commuters might well be inefficient.

Fourth, it is shown that, even in a monocentric city where commuting expenses should not be deductible from an efficiency point of view, a majority of long-distance commuters might vote in favor of a deduction since it redistributes towards commuters. Beyond the normative approach, this result is an additional explanation for the existence of deductions in many countries.

\section{References}

Alonso, W. (1964). Location and Land Use. Harvard University Press. Cambridge, Mass. 
Calthrop, E. (2001). On Subsidising Auto-Commuting. CESifo Working Paper 566. Munich.

Chia, N.-C., AKC Tsui, J. Whalley (2001). Ownership and Use Taxes as Congestion Correcting Instruments. NBER Working Paper 8278.

Due, J.F. (1977). Personal Deductions. In: J.A. Pechman, (Ed.). Comprehensive Income Taxation. The Brookings Institution. Washington, D.C.

Mirrlees, J.A. (1972). The Optimum Town. Scandinavian Journal of Economics 74. 114 $-135$.

Muth, R. (1969). Cities and Housing. University of Chicago Press. Chicago.

Oscar Faber, Open University and Amsterdam Free University (2000). Report for the European Commission DG TREN: Fair and Efficient Pricing in Transport - The Role of Charges and Taxes. http://www.epomm.org/

OECD (1993a). Environmental Taxes in OECD Countries: A Survey. Paris.

OECD (1993b). Taxation in OECD Countries. Paris.

Open University (2001). The Potential for Further Changes to the Personal Taxation Regime to Encourage Modal Shift. http://www.dft.gov.uk/

Parry, I.W.H. (2002). Comparing the Efficiency of Alternative Policies for Reducing Traffic Congestion. Journal of Public Economics 85. 333 - 362.

Wildasin, D.E. (1986). Spatial Variation of the Marginal Utility of Income and Unequal Treatment of Equals. Journal of Urban Economics 19. 125 - 129.

Wrede, M. (2000). Tax Deductibility of Commuting Expenses and Leisure: On the Tax Treatment of Time-Saving Expenditure. Finanzarchiv N.F. 57. 216 - 224.

Wrede, M. (2001). Should Commuting Expenses Be Tax Deductible? A Welfare Analysis. Journal of Urban Economics 49. 80 - 99. 


\section{Appendix: Optimum allocation of space}

The maximum principle conditions are

$$
\begin{aligned}
& \frac{\partial \mathrm{H}}{\partial \mathrm{a}}=\lambda_{1} \frac{\mathrm{u}_{\mathrm{h}} \mathrm{H}}{\mathrm{u}_{\mathrm{c}} \mathrm{N}^{2}}+\lambda_{2}=0, \\
& \dot{\lambda}_{1}=-\frac{\partial \mathrm{H}}{\partial \mathrm{c}}=-\left\{\mathrm{Nu}_{\mathrm{c}}+\lambda_{1} \frac{\mathrm{H}}{\mathrm{N}^{2}} \mathrm{a} \frac{\mathrm{u}_{\mathrm{hc}} \mathrm{u}_{\mathrm{c}}-\mathrm{u}_{\mathrm{cc}} \mathrm{u}_{\mathrm{h}}}{\mathrm{u}_{\mathrm{c}}^{2}}-\lambda_{3} \mathrm{~N}\right\}, \\
& \dot{\lambda}_{2}=-\frac{\partial \mathrm{H}}{\partial \mathrm{N}}=-\left\{\mathrm{u}-\mathrm{u}_{\mathrm{h}} \frac{\mathrm{H}}{\mathrm{N}}+\lambda_{1} \frac{\mathrm{H}^{2}}{\mathrm{~N}^{4}} \mathrm{a} \frac{\mathrm{u}_{\mathrm{c}}\left(-\mathrm{u}_{\mathrm{hh}}-2 \mathrm{u}_{\mathrm{h}} \mathrm{N} / \mathrm{H}\right)+\mathrm{u}_{\mathrm{h}} \mathrm{u}_{\mathrm{ch}}}{\mathrm{u}_{\mathrm{c}}^{2}}-\lambda_{3}(\mathrm{c}+\mathrm{kt})-\lambda_{4}\right\}, \\
& \dot{\lambda}_{3}=-\frac{\partial \mathrm{H}}{\partial \mathrm{X}}=0 \text { and } \dot{\lambda}_{4}=-\frac{\partial \mathrm{H}}{\partial \mathrm{M}}=0 .
\end{aligned}
$$

Using the first condition yields

$$
\begin{aligned}
\left(\frac{\dot{\mathrm{H}}}{\partial \mathrm{a}}\right)= & \dot{\lambda}_{1} \frac{\mathrm{u}_{\mathrm{h}}}{\mathrm{u}_{\mathrm{c}}} \frac{\mathrm{H}}{\mathrm{N}^{2}}+\dot{\lambda}_{2}+\lambda_{1} \frac{\mathrm{u}_{\mathrm{h}}}{\mathrm{u}_{\mathrm{c}}} \frac{\mathrm{H}^{2}}{\mathrm{~N}^{4}} \mathrm{a} \frac{\mathrm{u}_{\mathrm{hc}} \mathrm{u}_{\mathrm{c}}-\mathrm{u}_{\mathrm{cc}} \mathrm{u}_{\mathrm{h}}}{\mathrm{u}_{\mathrm{c}}^{2}} \\
& +\lambda_{1} \frac{\mathrm{H}^{2}}{\mathrm{~N}^{4}} \mathrm{a} \frac{\mathrm{u}_{\mathrm{c}}\left(-\mathrm{u}_{\mathrm{hh}}-2 \mathrm{u}_{\mathrm{h}} \mathrm{N} / \mathrm{H}\right)+\mathrm{u}_{\mathrm{h}} \mathrm{u}_{\mathrm{ch}}}{\mathrm{u}_{\mathrm{c}}^{2}} \\
= & 0 .
\end{aligned}
$$

Substituting for $\dot{\lambda}_{1}$ and $\dot{\lambda}_{2}$ and dividing by $\mathrm{h}$ yields

$$
\lambda_{3} \frac{\mathrm{u}_{\mathrm{h}}}{\mathrm{u}_{\mathrm{c}}}-\frac{\mathrm{u}}{\mathrm{h}}+\lambda_{3}\left(\frac{\mathrm{c}}{\mathrm{h}}+\frac{\mathrm{k}}{\mathrm{h}} \mathrm{t}\right)+\frac{\lambda_{4}}{\mathrm{~h}}=0
$$

Using $\dot{\mathrm{c}}=\left(\mathrm{u}_{\mathrm{h}} / \mathrm{u}_{\mathrm{c}}\right)(\mathrm{h} / \mathrm{N}) \dot{\mathrm{N}}$, the derivative is

$$
\lambda_{3}\left(\left(\frac{\dot{\mathrm{u}}_{\mathrm{h}}}{\mathrm{u}_{\mathrm{c}}}\right)+\frac{\mathrm{k}}{\mathrm{h}}\right)-\frac{\dot{\mathrm{u}}}{\mathrm{h}}+\frac{\dot{\mathrm{N}}}{\mathrm{N}}\left(\lambda_{3} \frac{\mathrm{u}_{\mathrm{h}}}{\mathrm{u}_{\mathrm{c}}}-\frac{\mathrm{u}}{\mathrm{h}}+\lambda_{3}\left(\frac{\mathrm{c}}{\mathrm{h}}+\frac{\mathrm{k}}{\mathrm{h}} \mathrm{t}\right)+\frac{\lambda_{4}}{\mathrm{~h}}\right)=0
$$

and thus $\left(\mathrm{u}_{\mathrm{h}} / \mathrm{u}_{\mathrm{c}}\right)=-\mathrm{k} / \mathrm{h}$, since the shadow price of resources $\lambda_{3}$ is not zero. 


\section{CESifo Working Paper Series}

(for full list see www.cesifo.de)

905 Kai A Konrad, Inverse Campaigning, April 2003

906 Lars P. Feld and Stefan Voigt, Economic Growth and Judicial Independence: Cross Country Evidence Using a New Set of Indicators, April 2003

907 Giuseppe Bertola and Pietro Garibaldi, The Structure and History of Italian Unemployment, April 2003

908 Robert A.J. Dur and Otto H. Swank, Producing and Manipulating Information, April 2003

909 Christian Gollier, Collective Risk-Taking Decisions with Heterogeneous Beliefs, April 2003

910 Alexander F Wagner, Mathias Dufour, and Friedrich Schneider, Satisfaction not Guaranteed - Institutions and Satisfaction with Democracy in Western Europe, April 2003

911 Ngo Van Long, Raymond Riezman, and Antoine Soubeyran, Trade, Wage Gaps, and Specific Human Capital Accumulation, April 2003

912 Andrea Goldstein, Privatization in Italy 1993-2002: Goals, Institutions, Outcomes, and Outstanding Issues, April 2003

913 Rajshri Jayaraman and Mandar Oak, The Signaling Role of Municipal Currencies in Local Development, April 2003

914 Volker Grossmann, Managerial Job Assignment and Imperfect Competition in Asymmetric Equilibrium, April 2003

915 Christian Gollier and Richard Zeckhauser, Collective Investment Decision Making with Heterogeneous Time Preferences, April 2003

916 Thomas Moutos and William Scarth, Some Macroeconomic Consequences of Basic Income and Employment Subsidies, April 2003

917 Jan C. van Ours, Has the Dutch Miracle Come to an End?, April 2003

918 Bertil Holmlund, The Rise and Fall of Swedish Unemployment, April 2003

919 Bernd Huber and Marco Runkel, Optimal Design of Intergovernmental Grants under Asymmetric Information, April 2003

920 Klaus Wälde, Endogenous Business Cycles and Growth, April 2003 
921 Ramon Castillo and Stergios Skaperdas, All in the Family or Public? Law and Appropriative Costs as Determinants of Ownership Structure, April 2003

922 Peter Fredriksson and Bertil Holmlund, Improving Incentives in Unemployment Insurance: A Review of Recent Research, April 2003

923 Bernard M.S. van Praag and Adam S. Booij, Risk Aversion and the Subjective Time Discount Rate: A Joint Approach, April 2003

924 Yin-Wong Cheung, Kon S. Lai, and Michael Bergman, Dissecting the PPP Puzzle: The Unconventional Roles of Nominal Exchange Rate and Price Adjustment, April 2003

925 Ugo Trivellato and Anna Giraldo, Assessing the 'Choosiness' of Job Seekers. An Exploratory Approach and Evidence for Italy, April 2003

926 Rudi Dornbusch and Stanley Fischer, International Financial Crises, April 2003

927 David-Jan Jansen and Jakob de Haan, Statements of ECB Officials and their Effect on the Level and Volatility of the Euro-Dollar Exchange Rate, April 2003

928 Mario Jametti and Thomas von Ungern-Sternberg, Assessing the Efficiency of an Insurance Provider - A Measurement Error Approach, April 2003

929 Paolo M. Panteghini and Guttorm Schjelderup, Competing for Foreign Direct Investments: A Real Options Approach, April 2003

930 Ansgar Belke, Rainer Fehn, and Neil Foster, Does Venture Capital Investment Spur Employment Growth?, April 2003

931 Assar Lindbeck, Sten Nyberg, and Jörgen W. Weibull, Social Norms and Welfare State Dynamics, April 2003

932 Myrna Wooders and Ben Zissimos, Hotelling Tax Competition, April 2003

933 Torben M. Andersen, From Excess to Shortage - Recent Developments in the Danish Labour Market, April 2003

934 Paolo M. Panteghini and Carlo Scarpa, Irreversible Investments and Regulatory Risk, April 2003

935 Henrik Jacobsen Kleven and Claus Thustrup Kreiner, The Marginal Cost of Public Funds in OECD Countries. Hours of Work Versus Labor Force Participation, April 2003

936 Klaus Adam, George W. Evans, and Seppo Honkapohja, Are Stationary Hyperinflation Paths Learnable?, April 2003

937 Ulrich Hange, Education Policy and Mobility: Some Basic Results, May 2003 
938 Sören Blomquist and Vidar Christiansen, Is there a Case for Public Provision of Private Goods if Preferences are Heterogeneous? An Example with Day Care, May 2003

939 Hendrik Jürges, Kerstin Schneider, and Felix Büchel, The Effect of Central Exit Examinations on Student Achievement: Quasi-experimental Evidence from TIMSS Germany, May 2003

940 Samuel Bentolila and Juan F. Jimeno, Spanish Unemployment: The End of the Wild Ride?, May 2003

941 Thorsten Bayindir-Upmann and Anke Gerber, The Kalai-Smorodinsky Solution in Labor-Market Negotiations, May 2003

942 Ronnie Schöb, Workfare and Trade Unions: Labor Market Repercussions of Welfare Reform, May 2003

943 Marko Köthenbürger, Tax Competition in a Fiscal Union with Decentralized Leadership, May 2003

944 Albert Banal-Estañol, Inés Macho-Stadler, and Jo Seldeslachts, Mergers, Investment Decisions and Internal Organisation, May 2003

945 Kaniska Dam and David Pérez-Castrillo, The Principal-Agent Matching Market, May 2003

946 Ronnie Schöb, The Double Dividend Hypothesis of Environmental Taxes: A Survey, May 2003

947 Erkki Koskela and Mikko Puhakka, Stabilizing Competitive Cycles with Distortionary Taxation, May 2003

948 Steffen Huck and Kai A. Konrad, Strategic Trade Policy and Merger Profitability, May 2003

949 Frederick van der Ploeg, Beyond the Dogma of the Fixed Book Price Agreement, May 2003

950 Thomas Eichner and Rüdiger Pethig, A Microfoundation of Predator-Prey Dynamics, May 2003

951 Burkhard Heer and Bernd Süssmuth, Cold Progression and its Effects on Income Distribution, May 2003

$952 \mathrm{Yu}-\mathrm{Fu}$ Chen and Michael Funke, Labour Demand in Germany: An Assessment of NonWage Labour Costs, May 2003

953 Hans Gersbach and Hans Haller, Competitive Markets, Collective Decisions and Group Formation, May 2003

954 Armin Falk, Urs Fischbacher, and Simon Gächter, Living in Two Neighborhoods Social Interactions in the LAB, May 2003 
955 Margarita Katsimi, Training, Job Security and Incentive Wages, May 2003

956 Clemens Fuest, Bernd Huber, and Jack Mintz, Capital Mobility and Tax Competition: A Survey, May 2003

957 Edward Castronova, The Price of 'Man' and 'Woman': A Hedonic Pricing Model of Avatar Attributes in a Synthetic World, June 2003

958 Laura Bottazzi and Marco Da Rin, Financing Entrepreneurial Firms in Europe: Facts, Issues, and Research Agenda, June 2003

959 Bruno S. Frey and Matthias Benz, Being Independent is a Great Thing: Subjective Evaluations of Self-Employment and Hierarchy, June 2003

960 Aaron Tornell and Frank Westermann, Credit Market Imperfections in Middle Income Countries, June 2003

961 Hans-Werner Sinn and Wolfgang Ochel, Social Union, Convergence and Migration, June 2003

962 Michael P. Devereux, Measuring Taxes on Income from Capital, June 2003

963 Jakob de Haan, Jan-Egbert Sturm and Bjørn Volkerink, How to Measure the Tax Burden on Labour at the Macro-Level?, June 2003

964 Harry Grubert, The Tax Burden on Cross-Border Investment: Company Strategies and Country Responses, June 2003

965 Kirk A. Collins and James B. Davies, Measuring Effective Tax Rates on Human Capital: Methodology and an Application to Canada, June 2003

966 W. Steven Clark, Using Micro-Data to Assess Average Tax Rates, June 2003

967 Christopher Heady, The 'Taxing Wages' Approach to Measuring the Tax Burden on Labour, June 2003

968 Michael P. Devereux and Alexander Klemm, Measuring Taxes on Income from Capital: Evidence from the UK, June 2003

969 Bernhard Eckwert and Itzhak Zilcha, The Effect of Better Information on Income Inequality, June 2003

970 Hartmut Egger and Josef Falkinger, The Role of Public Infrastructure for Firm Location and International Outsourcing, June 2003

971 Dag Morten Dalen and Trond E. Olsen, Regulatory Competition and Multi-national Banking, June 2003

972 Matthias Wrede, Tax Deductibility of Commuting Expenses and Residential Land Use with more than one Center, June 2003 